\section{Social inequalities in neonatal mortality and living condition}

\section{Desigualdades sociais na mortalidade neonatal e condição de vida}

\section{Annelise C. Gonçalves'}

Maria da Conceição N. Costa"

Jairnilson S. Paim"

Ligia Maria Vieira da Silva"

José Ueleres Braga'I'

\section{Mauricio Barreto"}

'Escola de Enfermagem da Universidade Federal do Rio Grande do Sul - Porto Alegre (RS), Brazil.

"Instituto de Saúde Coletiva, Universidade Federal da Bahia - Salvador (BA), Brazil.

"'Universidade Estadual do Rio de Janeiro - Rio de Janeiro (RJ), Brazil.

Note: This study is part of the project "Inequality trends in morbidity and mortality in urban space" developed by the Instituto de Saúde Coletiva, Universidade Federal da Bahia.

Corresponding author: Maria da Conceição N. Costa. Rua Alfredo Gomes de Oliveira, s/n, Canela, CEP: 41750-090, Salvador, BA, Brazil. E-mail: mcncosta@ufba.br

Financial support: Financial support: Conselho nacional de Desenvolvimento Científico e Tecnológico / CNPq Project No. 409628/2006-9; Announcement MCT-CNPq / MS-SCTIE-DECIT - No. 26/2006.

Conflict of interests: nothing to declare.

\section{Abstract}

Objective: To evaluate the association between the spatial distribution of neonatal mortality and living conditions, and to analyze trends in the social inequalities, related to this mortality, in Salvador, Bahia, Brazil, 2000 - 2006. Methods: The city's Information Zones, the unit of analysis used in this study, were grouped into strata reflecting high, intermediate, low and very low living conditions, based on a living conditions index (LCI). Neonatal mortality rates were calculated for each stratum. Spearman's correlation, linear regression and relative risks were used in the data analysis. Results: Neonatal mortality in Salvador was found to be associated with living conditions, with risks of 53, 56 and 59\% greater, respectively, in the intermediate, low and very low strata, when compared to the high living conditions stratum. Only the intermediate living conditions stratum shows a significant decline in neonatal mortality ( $\beta=-0.93 ; p=0.039$ ). In the stratum of high living conditions, it was observed a stagnation of this mortality. Conclusions: Poorer living conditions were associated to higher risks of neonatal mortality. The slight decline in social inequalities, found in neonatal mortality, was due to a decline in the intermediate living conditions stratum. Although dependent on the access to quality healthcare services and life support technologies, a more consistent reduction in the neonatal mortality and its associated inequalities will only be achieved when broader-reaching public policies are implemented, improving the living conditions, and mainly focusing on priority groups.

Keywords: Infant mortality. Social conditions. Health inequalities. Social conditions. Mortality. Risk factors. 


\section{Resumo}

Objetivos: Avaliar a associação entre distribuição espacial da mortalidade neonatal e condições de vida, e analisar as tendências das desigualdades sociais relacionadas a essa mortalidade, em Salvador, Bahia, Brasil, 2000 - 2006. Métodos: As Zonas de Informação da cidade, a unidade de análise utilizada nesse estudo, foram agrupadas em estratos de alta, intermediária, baixa $\mathrm{e}$ muito baixa condições de vida, com base em um Índice de Condições de Vida (ICV). Taxas de mortalidade neonatal foram calculadas para cada estrato. Correlação de Spearman, regressão linear e riscos relativos foram utilizados na análise de dados. Resultados: a mortalidade neonatal em Salvador mostrou-se associada às condições de vida, com risco de 53, 56 e 59\% maior, respectivamente, nos estratos intermediários, baixa e muito baixa em comparação com o de alta condição de vida. Somente o estrato de condições de vida intermediário mostrou uma queda significativa na mortalidade neonatal $(\beta=-0,93, p=0,039)$. No estrato de condições de vida elevado, observou-se a estagnação desta mortalidade. Conclusões: Piores condições de vida foram associadas a maiores riscos de mortalidade neonatal. A ligeira redução das desigualdades sociais encontradas na mortalidade neonatal foi devida ao declínio na mortalidade do estrato de intermediária condição de vida. Embora dependente do acesso a serviços de qualidade de saúde e tecnologias de suporte à vida, uma redução mais consistente da mortalidade neonatal e das desigualdades só será alcançada quando forem implementadas políticas públicas de mais amplo alcance, melhorando as condições de vida, focalizando, principalmente, em grupos prioritários.

Palavras-chave: Mortalidade infantil. Condições sociais. Desigualdades em saúde. Condições sociais. Mortalidade. Fatores de risco.

\section{Introduction}

The relevance of social processes in the occurrence and distribution of diseases in human populations has been confirmed in numerous studies. One of the approaches to increase understanding of this relationship uses living conditions as a category of analysis, in which these are defined as the material conditions of existence of a given population ${ }^{1}$. The role of living conditions in determining health problems has been evaluated, particularly in studies dealing with the determinants of infant mortality ${ }^{2-4}$.

Concerning neonatal mortality, as well as factors related to the quality of healthcare services, living conditions are considered equally important ${ }^{5-7}$. Studies relating living conditions with health differentials in populations, in general, indicate the existence of a socioeconomic gradient in which groups economically more deprived are in disadvantage compared to the most affluent.

Living conditions vary between groups and social classes in accordance with modes of appropriation and distribution of wealth in a historically situated social formation. These social differences are also reflected in the process of occupation of space $^{8}$, and for this reason, the distribution of disease in the socio-geographical space is used as a strategy to study the social determination of diseases ${ }^{1,2,4,5,7,9-11}$, enabling identification of possible differential factors in health resulting from social inequalities.

Striking differences are found in the distribution of neonatal mortality between the different regions of the world, reflecting existing social inequalities ${ }^{12}$. For example, in 2004, the average neonatal mortality rate in Africa was 34 per 1,000 live births, approximately 8.5 times the rate found in developed countries, where the rate is around 4 per 1,000 live births ${ }^{13}$.

Evidence resulting from studies, carried out both worldwide ${ }^{14,15}$ and in Brazil ${ }^{16-19}$, show that the mediation of factors related to maternal and child healthcare in the determination of neonatal mortality is affected by living conditions. Therefore, social 
inequalities also affect access to neonatal healthcare ${ }^{20}$. In this context, reducing the extent of the social inequalities related to neonatal mortality represents a challenge to the health authorities, particularly in less developed countries. This concern is pertinent, since a persistently high risk of neonatal mortality is a factor that contributes greatly towards decelerating the decline in infant mortality or even preventing a decline $\mathrm{e}^{21,22}$.

Since the 1990s, neonatal deaths in Brazil have been responsible for the largest proportion of infant mortality ${ }^{16,23-26}$. In 2008, the neonatal mortality rate was 10.3 per 1,000 live births ${ }^{27}$ and, despite a decline of $24.3 \%$ compared to the year 2000 , this rate was 2.6 and 2.1 times higher, respectively, in the same year compared to the rate for developed countries and countries with a similar degree of development ${ }^{28}$. Instead of the decline in the neonatal mortality rate that was occurring in the country, there is now a tendency towards stabilization at levels that remain high $^{24}$. Furthermore, significant inequalities have been found in the distribution of the neonatal mortality rate within the different urban spaces and social groups $s^{3,7}$.

Notwithstanding, in recent decades, Brazil has been the target of a variety of public policies aimed at the low-income population, particularly in the field of education and health ${ }^{29}$. In Salvador, in the same period, access to basic services and consumer goods has also improved and the human development index (HDI) and per capita income have risen ${ }^{30}$. Therefore, considering the increased vulnerability of children under one year of age to social policies, albeit compensatory, it has to be admitted that these actions may be capable of reducing the discrepancies in infant mortality rates between different social groups, resulting in a tendency of the rates to converge and reduction of the social inequalities associated with infant mortality, including its neonatal component.

The objective of this study was to evaluate the association between spatial distribution of neonatal mortality and living conditions in Salvador, Bahia, Brazil and to analyze the trend in social inequalities related to this mortality between 2000 and 2006 under the assumption that the decline found in the risk of the neonatal death during this period was higher in areas of greater deprivation.

\section{Methods}

An ecological study was carried out in which the unit of analysis was the information zone (IZ), corresponding to areas into which the Metropolitan Region Development Company (CONDER) subdivided the city of Salvador, (Brazil), based on socioeconomic, physical and administrative infrastructure and planning criteria, on compatibility with the census sectors defined by the Brazilian Institute of Geography and Statistics $(\text { IBGE) })^{31}$.

Data derived from birth and death certificates were supplied in digital form (CD-ROM) by the Bureau of Health Statistics of Salvador's Municipal Health Department ${ }^{32}$. The LOCALIZA ${ }^{33}$ software, developed at the Collective Health Institute of the Federal University of Bahia, and the Google Earth internet tool were used to geo-reference the addresses given on the birth and death certificates. Demographic and socioeconomic data from the 2000 demographic census were obtained from IBGE ${ }^{34}$. CONDER supplied the digital maps for each IZ (cartographic maps of the municipality) in shapefile format (shp), which is compatible with the ArcView GIS software, version 3.2 and TerraView.

Neonatal mortality rate (and its components of early and late neonatal deaths) and the living conditions index (LCI) for the year 2000 were the indicators used. The option for the use of a composite indicator instead of a multivariate analysis, including relevant variables, was mainly because we aren't seeking to show causal associations, but different patterns resulting from the interaction between social and biological processes from a more totalizing perspective. Furthermore, this strategy 
allowed the comparison with results of previous infant mortality studies performed in Salvador, using the same approach.

The LCI, as constructed by Paim et al. ${ }^{9}$, corresponds to a composite index for each IZ, based on five proxy variables of living conditions derived from the 1991 census: income, education, sanitation, slum and people per bedroom. However, for the present study, this latter indicator could not be reproduced exactly because the information on the number of rooms serving as bedrooms per census sector for the year 2000 was unavailable. Then, it was used the people per room ratio. Three indicators (slum, income and the number of people per room) were listed in increasing order, while the remaining two (education and sanitation) were listed in decreasing order. A score was awarded, consisting of consecutive values, starting at 1 , in accordance with their position in this order. The sum of the values of this score resulted in an overall score (LCI) for each IZ. These were arranged in increasing order and grouped into strata of relatively homogenous IZ, reflecting the strata of the population classified as having high, intermediate, low and very low living conditions. Higher LCI scores correspond to poorer living conditions. The neonatal mortality rate and its components were calculated for each IZ and stratum.

Spearman's correlation test was used to conduct an exploratory analysis of the association between the average annual neonatal mortality rate (and its components) for the 2000 - 2006 period and the LCI scores for each IZ. Social inequality in neonatal mortality was examined, together with its extent and trends, during the study period, by performing simple linear regression analysis and calculating relative risk (year by year for the 2000 2006 period), considering the high living conditions stratum as a reference, with a 95\% confidence interval.

The study protocol was approved by the Internal Review Board of the Collective Health Institute, Federal University of Bahia (\#012-09 CEP-ISC).

\section{Results}

Between 2000 and 2006, 5,097 neonatal deaths and 271,840 live births were registered to mothers living in Salvador. Only $8.0 \%$ of these deaths, and $0.7 \%$ of the births, could not be geo-referenced, because the addresses were missing or incomplete. The neonatal mortality rate for the municipality in this period, calculated from the geo-referenced data, was 17.4 per 1,000 live births.

Correlating the IZs with their respective LCI values, it was found that those with the most favorable living conditions were, in general, concentrated in the southern and eastern areas of the city, along a coastal strip, while the majority of the IZs, in which living conditions were low or very low, were found to be situated in the city center and in the western and northern areas. The majority of zones, in which living conditions were classified as intermediate, were situated in the southern part of the city, close to the IZs in which living conditions were classified as high. Neonatal mortality correlated positively with the living conditions index $(r=0.2970$; $\mathrm{p}=0.049$ ), the same being true when early neonatal deaths were evaluated as a separate component $(\mathrm{r}=0.3054 ; \mathrm{p}=0.0031)$.

When the data are analyzed yearby-year, high rates of neonatal mortality (ranging from 20.0 per 1,000 live births in 2000 to 17.1 per 1,000 live births in 2006) and substantial fluctuations in the velocity of the annual decline in neonatal mortality in each stratum of living conditions are noted. If compared only the first and final years of the study period, the risk of neonatal death in the high living conditions stratum remained largely unchanged, whereas an increase was found in the very low living conditions stratum and a decline in the other strata (Table 1). The median neonatal mortality rate was $11.8 / 1,000 \mathrm{NV}$ in the stratum of high life condition, and $16.9 / 1,000 \mathrm{NV}$ in the very low standard of living. Among the lower stratum (19.0\%) and very low life condition (16.9\%), there was a reduction of $11.1 \%$ in the value of this indicator (Figure). 
However, linear regression analysis (Table 2) showed a decline in the annual neonatal mortality rates in all living conditions strata, with the greatest decline ( $\beta=-0.93$ ) being found in the intermediate living conditions stratum, which was also the only stratum in which a statistically significant difference was found $(\mathrm{p}=0.038)$. The smallest decline was found in the very low living conditions stratum $(\beta=-0.021$; $\mathrm{p}=0.959$ ). Similar results were found for the early neonatal death component, except

Table 1 - Neonatal mortality rate and annual variation according to strata living conditions and year of occurrence. Salvador, (BA), Brazil, 2000 - 2006.

Tabela 1 - Taxa de mortalidade neonatal e variação anual de acordo com estratos de condições de vida e ano de ocorrência. Salvador (BA), Brasil, $2000-2006$

\begin{tabular}{lcccccccc}
\hline Living condition & \multicolumn{2}{c}{ High } & \multicolumn{2}{c}{ Intermediate } & \multicolumn{2}{c}{ Low } & \multicolumn{2}{c}{ Very low } \\
\hline Year & NMR & Var\% & NMR & Var\% & NMR & Var\% & NMR & Var\% \\
\hline 2000 & 10.0 & - & 20.0 & - & 18.8 & - & 17.2 & - \\
2001 & 12.3 & 23.7 & 18.7 & -6.6 & 18.2 & -3.6 & 19.7 & 14.3 \\
2002 & 12.9 & 4.7 & 17.6 & -5.8 & 18.1 & -0.3 & 20.7 & 5.2 \\
2003 & 9.7 & -24.7 & 14.9 & -15.9 & 19.7 & 8.9 & 20.4 & -1.8 \\
2004 & 11.6 & 19.5 & 17.3 & 16.7 & 16.9 & -14.3 & 14.1 & -30.9 \\
2005 & 11.8 & 1.4 & 16.7 & -3.8 & 17.5 & 3.7 & 17.4 & 23.6 \\
2006 & 10.2 & -13.2 & 17.1 & 2.6 & 15.5 & -11.3 & 18.0 & 3.6 \\
$2000-2006$ & 11.5 & 2.6 & 17.5 & -14.7 & 18.0 & -17.5 & 18,3 & 4.6 \\
\hline
\end{tabular}

*Rates per 1000 live births. NMR: neonatal mortality rate; Var\%: annual variation.

*Taxas por 1000 nascidos vivos. NMR: taxa de mortalidade neonatal; Var\%: variação anual.

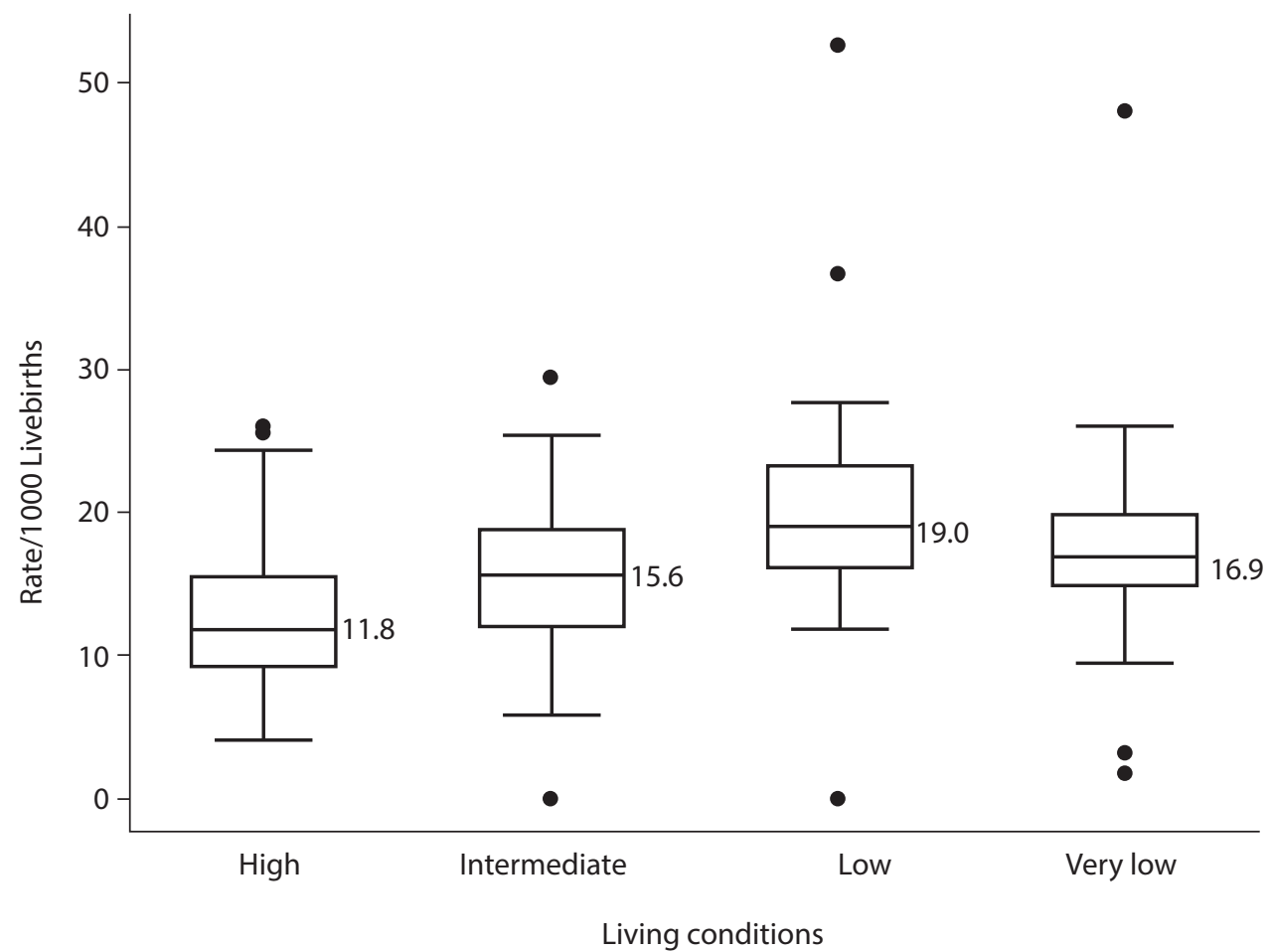

Figure - Neonatal mortality rates according to living conditions strata. Salvador (BA), Brazil, 2000 - 2006.

Figura - Taxas de mortalidade neonatal de acordo com estratos de condições de vida. Salvador (BA), Brasil, 2000 - 2006. 
that, in this case, the difference found in the intermediate living conditions stratum was not statistically significant $(p=0.055)$. Concerning the late deaths component, a slight increase was found in the high and very low living conditions strata over the study period, while in the intermediate and low living conditions strata a decline occurred, with a tendency towards stabilization in the latter.

For the 2000-2006 period, as a whole, the average neonatal mortality rate was found to be lowest in the stratum in which living conditions were classified as high (11.5 per 1,000 live births). Results were similar when the early neonatal death rate was calculated as a separate component (9.0 per 1,000 live births). In the intermediate, low and very low living conditions strata, these indicators were $17.5,18.0$ and 18.3 per 1,000 live births, respectively. Overall, around $80 \%$ of these cases consisted of early neonatal deaths. The relative risk (RR) of neonatal death and early neonatal death increased as living conditions deteriorated, neonatal mortality being 53,56 and $59 \%$ higher in the intermediate, low and very low living conditions strata compared to the high living conditions stratum. These differences were statistically significant (Table 3).

As only the years of 2000 and 2006 are being taken into account, a greater decline (15.0\%) in the RR of neonatal death was found in the intermediate living conditions stratum.

\section{Discussion}

The gradient found in the relationship between neonatal mortality and living conditions in the population in Salvador, Bahia, Brazil for the 2000 - 2006 period suggests that its distribution is a consequence

Table 2 - Linear regression coefficients ( $\beta$ ) for the association between neonatal, early neonatal and late neonatal mortality rates and year of occurrence of death according strata of living conditions. Salvador (BA), Brazil, 2000 - 2006. Tabela 2 - Coeficientes de regressão linear ( $\beta$ ) para a associação entre mortalidade neonatal, neonatal precoce e neonatal tardia e ano de ocorrência do óbito de acordo com estratos de condições de vida. Salvador (BA), Brasil, 2000 - 2006.

\begin{tabular}{lcccccc}
\hline \multirow{2}{*}{ Living condition } & \multicolumn{2}{c}{ Neonatal Mortality } & \multicolumn{2}{c}{ Early neonatal mortality } & \multicolumn{2}{c}{ Late neonatal mortality } \\
\cline { 2 - 6 } & $\beta$ & $\mathrm{p}$-value & $\beta$ & $\mathrm{p}$-value & $\beta$ & $\mathrm{p}$-value \\
\hline High & -0.17 & 0.717 & -0.31 & 0.487 & 0.14 & 0.474 \\
Intermediate & -0.93 & 0.038 & -0.76 & 0.055 & -0.17 & -0.416 \\
Low & -0.16 & 0.629 & -0.17 & 0.580 & 0.003 & 0.979 \\
Very low & -0.021 & 0.959 & -0.18 & 0.635 & 0.16 & 0.328 \\
\hline
\end{tabular}

Table 3 - Neonatal, early neonatal and late neonatal mortality rates* and relative risk according to strata of living conditions. Salvador (BA), Brazil, 2000 - 2006.

Tabela 3 - Taxas de mortalidade neonatal, neonatal precoce e neonatal tardia e risco relativo de acordo com estratos de condições de vida. Salvador (BA), Brasil, 2000 - 2006.

\begin{tabular}{lccccccccc}
\hline \multirow{2}{*}{ Living conditions } & \multicolumn{3}{c}{ Neonatal mortality } & \multicolumn{3}{c}{ Early Neonatal Mortality } & \multicolumn{3}{c}{ Late Neonatal Mortality } \\
\cline { 2 - 10 } & Rate & RR & $95 \% \mathrm{Cl}$ & Rate & RR & $95 \% \mathrm{Cl}$ & Rate & RR & $95 \% \mathrm{Cl}$ \\
\hline High & 11.5 & 1 & - & 9.0 & 1 & - & 2.5 & 1 & - \\
Intermediate & 17.5 & 1.53 & $1.33-1.74$ & 14.5 & 1.62 & $1.38-1.87$ & 3.0 & 1.21 & $0.89-1.63$ \\
Low & 18.0 & 1.56 & $1.37-1.76$ & 14.9 & 1.66 & $1.44-1.90$ & 3.0 & 1.21 & $0.92-1.59$ \\
Very Low & 18,3 & 1.59 & $1.39-1.79$ & 15.2 & 1.68 & $1.45-1.3$ & 3.1 & 1.25 & $0.95-1.65$ \\
\hline
\end{tabular}

*Per 1000 live births. RR: Relative Risk.

*A cada 1000 nascimentos com vida. RR: Risco Relativo. 
of social inequalities. This finding is consistent with the results of other similar studies on neonatal mortality developed in Brazil $^{3,7}$, and particularly with the findings of studies conducted in Salvador, in the 1980s and 1990s, showing that, the areas in which infant mortality rates were higher, were precisely those inhabited by the more socioeconomically disadvantaged segments of the population ${ }^{2,35,36}$. In general, the extremely deprived population is concentrated in these areas, which are marked by deficiencies in infrastructure and basic services ${ }^{37}$ that exert a negative effect on the health conditions of the resident population. For the city of Salvador as a whole, there was a slight decline with a trend towards stabilization in the neonatal mortality rate ${ }^{27}$. Nevertheless, when smaller population clusters in the city were examined, substantial differences were found in the velocity of decline, suggesting that some require greater surveillance and more effective actions.

The slight decline or almost no reduction in the risk of neonatal mortality found in the stratum of high living conditions may be indicative of predominance of causes of death, more difficult to be controlled in this stratum. Another possible hypothesis is the influence of higher proportion of cesarean deliveries, as has been observed in more developed areas, leading to greater frequency of live births with low birth weight or intrauterine growth retardation, which are important risk factors for neonatal mortality ${ }^{38-40}$. Moreover, as in this stratum, the prenatal, hospital care and better quality should be easier to access, the early detection of fetal problems and use of mechanisms of advanced life support may be helping to reduce the occurrence of stillbirths, but favoring the birth of children who previously would be considered unviable, although they are subject to early death ${ }^{41}$ and contribute, thereby, to neonatal death non-reduction. In addition, the lesser impact of improvements in the environment and in maternal education level in more affluent groups may constitute one of the explanations, as discussed by Goldani et al. ${ }^{19}$.

Although the causes of neonatal deaths - that can be reduced by simple technology and health actions to the maternal segment and to the child, at birth - predominate in strata of low and very low living conditions, it seems that more investment are needed, since also in the strata in which these conditions are more favorable, the reduction in neonatal mortality was found to be negligible.

It should be emphasized that the only significant decline in the risk of neonatal death was detected in the intermediate living conditions stratum, in which the highest risks of neonatal death were found at the beginning of the study. These high rates of neonatal mortality are surprising, since this stratum refers to a spatial population clustering in which the zones forming it are predominantly situated in the southern region of the city, close to the IZs with high living conditions. The average levels of the socioeconomic indicators, on which classification of the intermediate living conditions stratum are based on, are only less favorable than those in the high living conditions stratum. Similar results were found for the state of Paraná, between 1997 and 2001, when the lowest neonatal mortality rates were found in clusters of the highest and lowest socioeconomic strata, with little difference in the rates between the two strata. According to these authors, this may be a consequence of factors other than socioeconomic determinants, for example factors related to healthcare, and the role these factors may play in intermediating between living conditions and health status ${ }^{4}$. A similar hypothesis was raised when the expected relationship between neonatal mortality rate and living conditions was not found in the state of Rio de Janeiro at the beginning of the $1990 \mathrm{~s}^{5}$, and in the 
municipality of Rio de Janeiro in 1995 concerning infant mortality ${ }^{42}$, indicating a need for interventions focused on the realm of healthcare services. On the other hand, in a study in the state of Ceará, the authors credited this inverse relationship to the existence of a better notification system in the municipalities, with high rates of infant mortality and better socioeconomic conditions, and the under-notification of deaths in areas with low rates of infant mortality and poorer living conditions ${ }^{43}$. This may represent a plausible explanation for the finding of a higher neonatal mortality rate in the intermediate living conditions stratum compared to the low and very low living conditions strata in Salvador.

The limitations of this study are predominantly due to the quality of secondary data. Although in Salvador the Mortality Information System had coverage above $90 \%$ during the study period, some problems are still found as incorrect and incomplete filling of some fields in the Death Certificate $^{44}$, such as error in the classification of infant mortality (fetal/not fetal), as identified by Nascimento et al. ${ }^{45}$, in that municipality. Also, what may be affecting the results of this research, are limitations inherent to ecological studies that include the scale used, mobility inter and intra-area, and heterogeneity intra-areas of that city, which correspond to geographic pre-defined administrative-divisions, rather than more homogenous areas, as to socioeconomic conditions. Furthermore, although the findings contradict expectations regarding the living conditions stratum, in which the greatest decline in the risk of neonatal death was found, it is reasonable to affirm that some reduction occurred in the inequalities associated with neonatal mortality in this city, as a consequence of the decline in risk in the intermediate living conditions stratum of the population, potentiated by the negligible variation in risk in the high living conditions stratum. The sanitary authorities need to pay particular attention to the low living conditions strata in order to identify and intervene in the factors causing deceleration in the decline in neonatal mortality in this segment of the population.

Although the relevance of improvements and investments in prenatal care and childbirth in the prevention of neonatal deaths is recognized, the impact of healthcare and sanitary measures on infant mortality is limited, since they result in a decline up to a certain plateau, beyond which little progress is made, unless measures are implemented to deal with existing social inequalities ${ }^{46}$. If more effective efforts to reach disadvantaged groups are not implemented, these inequalities are likely to persist ${ }^{47,48}$. Therefore, reducing inequalities in health represents a necessary step towards reducing neonatal and infant mortality ${ }^{49}$, even in countries in which rates are $l_{0} w^{50}$. Concomitantly, actions dealing with multiple associated factors, that extend beyond healthcare should be implemented, such as education services and social work aimed at meeting the basic needs for guaranteeing pregnancy and childbirth in conditions favorable to safe survival, for instance ${ }^{5}$.

In Brazil, interventions in these areas havebeenhinderedduetoalackofefficiency and the fragility of public policies of social protection, aimed at combating poverty and social inequality ${ }^{51}$. This negatively affects any attempts to promote improvements in living conditions that, in turn, could result in an increase in the health levels of the population ${ }^{52}$. Therefore, in view of the situation concerning neonatal mortality in Salvador, it becomes imperative to define and implement more broad-reaching public policies, aimed at improving living conditions and promoting the quality of healthcare in maternal and child health. Although these policies should necessarily involve all segments of the population, attention should be focused on priority groups. 


\section{References}

1. Paim JS. Abordagens teórico-conceituais em estudos de condições de vida e saúde: notas para reflexão e ação. In: Barata RB, org. Condições de vida e situação de saúde. Rio de Janeiro: ABRASCO; 1997. p. 1-30.

2. Costa MCN, Azi PA, Paim J, Vieira-da-Silva LM. Mortalidade infantil e condições de vida: a reprodução das desigualdades sociais em saúde na década de 90. Cad Saúde Pública 2001; 17: 555-67.

3. Guimarães MJB, Marques NM, Melo Filho DA, Szwarcwald CL. Condição de vida e mortalidade infantil: diferenciais intra-urbanos no Recife, Pernambuco, Brasil. Cad Saúde Pública 2003; 19: 1413-24.

4. Andrade SM, Soares DA, Matsuo T, Souza RK, Mathias TA, Iwakura ML, Zequim MA. Condições de vida e mortalidade infantil no Estado do Paraná, Brasil, 1997/2001. Cad Saúde Pública 2006; 22: 181-9.

5. Leal MC, Szwarcwald CL. Características da mortalidade neonatal no Estado do Rio de Janeiro na década de 80: uma visão espaço-temporal. Rev Saúde Pública 1997; 31(5): 457-65.

6. Victora CG, Barros FC. Infant mortality due to perinatal causes in Brazil: trends, regional patterns and possible interventions. São Paulo Med J 2001; 119(1): 33-42.

7. Nascimento LF, Batista GT, Dias NW, Catelani CS, Becker D, Rodrigues L. Análise espacial da mortalidade neonatal no Vale do Paraíba, 1999 a 2001. Rev Saúde Pública 2007; 41(1): 94-100.

8. Santos M. Espaço e Método. São Paulo: Nobel; 1992. p. 120.

9. Paim JS, Silva LM, Costa MC, Prata PR, Lessa I. Desigualdades na situação de saúde do município de Salvador e relações com as condições de vida. Rev Ci Méd Biol 2003; 2: 30-9.

10. Donoso ES. Desigualdad en mortalidad infantil entre las comunas de la provincia de Santiago. Rev Med Chile 2004; 132(4): 461-6.

11. Terra de Souza AC, Cufino E, Peterson KE, Gardner J, Vasconcelos do Amaral MI, Ascherio A. Variations in infant mortality rates among municipalities in the state of Ceará, Northeast Brazil: an ecological analysis. Int J Epidemiol 1999; 28(2): 267-75.

12. Lawn JE, Cousens S, Zupan J. 4 million neonatal deaths: when? Where? Why? Lancet 2005; 365(9462): 891-900.

13. World Health Organization. Neonatal and perinatal estimates: country, regional and global estimatives 2004 . Geneva: World Health Organization; 2007.

14. Devlieger H, Martens G, Bekaert A. Social inequalities in perinatal and infant mortality in the northern region of Belgium (the Flanders). Eur J Public Health 2005; 15(1): 15-9.

15. Halder AK, Kabir M. Child mortality inequalities and linkage with sanitation facilities in Bangladesh. J Health Popul Nutr 2008; 26(1): 64-73.
16. Menezes AMB, Barros FC, Victora CG, Alves C, Rocha C, Albernaz E et al. Mortalidade perinatal em duas coortes de base populacional no sul do Brasil: tendências e diferenciais. Cad Saúde Públ 1996; 12(Suppl.1): 33-41.

17. Araújo BF, Bozzetti MC, Tanaka AC. Mortalidade Neonatal precoce em Caxias do Sul: um estudo de coorte. J Pediatria 2000; 76: 200-6.

18. De Andrade CLT, Szwarcwald CL. Análise espacial da mortalidade neonatal precoce do Município do Rio de Janeiro, 1995-1996. Cad Saúde Pública 2001; 17(5): 1199-210.

19. Goldani MZ, Benatti R, da Silva AA, Bettiol H, Correa JCW, Tietzmann $\mathrm{M}$ et al. Narrowing inequalities in infant mortality in Southern Brazil. Rev Saúde Pública 2002; 36(4): 478-83.

20. Campos D, Loschi RH, França E. Mortalidade neonatal precoce hospitalar em Minas Gerais: associação com variáveis assistenciais e a questão da subnotificação. Rev Bras Epidemiol 2007; 10(2): 223-38.

21. Leal MC, Szwarcwald CL. Evolução da mortalidade neonatal no estado do Rio de Janeiro, Brasil de 1979 a 1993: análise por causa segundo grupo de idade e região de residência. Cad Saúde Pública 1996; 12: 243-52.

22. Rede Interagencial de Informações para Saúde. Informe de situação e tendências: demografia e saúde. Brasília: Organização Pan-Americana da Saúde, 2009.

23. da Silva CF, Leite AJM, de Almeida NMGS, Gondim RC. Fatores de risco para mortalidade infantil em município do nordeste do Brasil: linkage entre bancos de dados de nascidos vivos óbitos infantis - 2000 a 2002. Rev Bras Epidemiol 2006; 9(1): 69-80.

24. de Morais Neto OL, Barros MBA. Fatores de risco para mortalidade neonatal e pós-neonatal na Região CentroOeste do Brasil: linkage entre bancos de dados de nascidosvivos e óbitos infantis. Cad Saúde Pública 2000; 16(2): 477-85.

25. Ribeiro VS, da Silva AAM. Tendências da mortalidade neonatal em São Luis, Maranhão, Brasil, de 1979 a 1996. Cad Saúde Pública 2000; 16(2): 429-38.

26. Cunha AJLA, Amaral JJ, Silva MAF. Evolução da mortalidade infantil no Brasil na última década: implicações para estratégias de controle. Rev Pediatria do Ceará 2001; 2: 9-12.

27. Ministério da Saúde. Indicadores e dados básicos - Brasil 2010. Available at http://w3. datasus. gov. br/datasus/ datasus.php (Accessed May 01, 2010).

28. World Health Organization. World Health Statistics 2010. Geneva: World Health Organization; 2010.

29. Cardoso FHC. Desenvolvimento social e políticas públicas de saúde. Brasília: Ministério da Saúde, 2006.

30. Programa das Nações Unidas para o Desenvolvimento. Atlas do Desenvolvimento Humano no Brasil. Perfil do Município de Salvador: Programa das Nações Unidas para o Desenvolvimento, 2004. 
31. Instituto Brasileiro de Geografia e Estatística. Cidades. Rio de Janeiro: Instituto Brasileiro de Geografia e Estatística. Available at http:// www. ibge. gov.br/ cidadesat/default. php (Accessed Nov 11, 2007).

32. Secretaria Municipal de Saúde de Salvador, Bahia. Dados SIM/SINASC. Salvador: Diretoria de Informação em Saúde; 2007.

33. Universidade Federal da Bahia/Instituto de Saúde Coletiva. LOCALIZA versão 2.0. Sistema de Georeferenciamento de Endereços em Unidades Territoriais; 2003.

34. Instituto Brasileiro de Geografia e Estatística. Censo 2000. Rio de Janeiro: Instituto Brasileiro de Geografia e Estatística. Available at http:// www. ibge. gov.br/ cidadesat/default. php (Accessed Nov 10, 2007).

35. Paim JS, Costa MC, Cabral V, Mota IA, Neves RB. Spatial distribuition of proportional infant mortality and certain socioeconomic variables in Salvador, Bahia, Brazil. Bull Pan Am Health Organ 1987; 21(3): 225-39.

36. Paim JS, Costa MC. Decline and unevenness of infant mortality in Salvador, Brazil, 1980-1988. Bull Pan Am Health Organ 1993; 27(1): 1-14.

37. Carvalho IM, Pereira GC (Coords).Como anda Salvador e sua região metropolitana. Salvador: EDUFBA. c2006. p. 185.

38. Barros FC, Victora CG, Matijasevich A, Santos IS, Horta BL, Silveira MF, Barros AJ. Preterm births, low birth weight, and intrauterine growth restriction in three birth cohorts in Southern Brazil: 1982, 1993 and 2004. Cad Saúde Pública 2008; 24(Suppl 3): S390-8.

39. Silva AA, Bettiol H, Barbieri MA, Pereira MM, Brito LG, Ribeiro VS, Aragão VMF. Why are the low birthweight rates in Brazil higher in richer than in poorer municipalities? Exploring the epidemiological paradox of low birthweight. Paediatr Perinat Epidemiol 2005; 19(1): 43-9.

40. Aragão VMF, Barbieri MA, Moura Da Silva AA, Bettiol $\mathrm{H}$, Ribeiro VS. Risk factors for intrauterine growth restriction: a comparison between two Brazilian cities. Pediatr Res. 2005; 57(5 Pt 1): 674-9.

41. Carvalho M, Gomes MASM. Mortalidade do prematuro extremo em nosso meio: realidade e desafios. J Pediatr 2005; 81(Suppl 1): S111-8.

42. Campos TP, Carvalho MS, Barcellos CC. Mortalidade infantil no Rio de Janeiro, Brasil: áreas de risco e trajetória dos pacientes até os serviços de saúde. Rev Panam Salud Publica 2000; 8(3): 164-71.
43. Bezerra Filho JG, Kerr LRFS, Miná DL, Barreto ML. Distribuição espacial da taxa de mortalidade infantil e principais determinantes no Ceará, Brasil, no período 2000-2002. Cad Saúde Pública 2007; 23(5): 1173-85.

44. Ministério da Saúde. Rede Interagencial de Informações para a Saúde. Indicadores de Dados Básicos - IDB 2006. Brasília: RIPSA; 2007. Availabe at http://tabnet.datasus.gov. br/cgi/idb2007/c01.htm (Accessed Nov 5,2007 ).

45. Do Nascimento EMR, Costa MCN, Mota ELA, Paim JS. Estudo de fatores de risco para óbitos de menores de um ano mediante compartilhamento de bancos de dados. Cad Saúde Pública, 2008; 24(11): 2593-2602.

46. Duarte CMR. Reflexos das políticas de saúde sobre as tendências da mortalidade infantil no Brasil: revisão da literatura sobre a última década. Cad Saúde Pública 2007; 23(7): 1511-28.

47. Victora CG, Wagstaff A, Schellenberg JA, Gwatkin D, Claeson M, Habicht JP. Applying an equity lens to child health and mortality: more of the same is not enough. Lancet 2003; 362(9379): 233-41.

48. Gwatkin DR, Bhuiya A, Victora CG. Making health systems more equitable. Lancet 2004; 364(9441): 1273-80.

49. Fenn B, Kirkwood BR, Popatia Z, Bradley DJ. Inequities in neonatal survival interventions: evidence from national survey. Arch Dis Child Fetal Neonatal 2007; 92(5): F361-6.

50. Judge K. Inequalities in infant mortality: patterns, trends, policy responses and emerging issues in Canada, Chile, Sweden and the United Kingdom. Health Sociology Review 2009; 18(1): 12-24.

51. Magalhães R, Burlandy L, Senna MCM. Desigualdades sociais, saúde e bem-estar: oportunidades e problemas no horizonte de políticas públicas transversais. Ciênc Saúde Coletiva 2007; 12(6): 1415-21.

52. Viana SM, Nunes A, Santos JR, Barata RB. Medindo as desigualdades em saúde no Brasil: uma proposta de monitoramento. Brasília: Organização Pan-Americana da Saúde/Instituto de Pesquisa Econômica Aplicada; 2001. p. 224.

Received on: 04/23/12

Final version presented on: 08/27/12

Accepted on: 10/31/12 